\title{
Assessment of the Carbon Emission Reduction Effects of Ecological River Slope Construction in China
}

Yuanhui $\mathrm{Yu}^{1,2}$, Weihua $\mathrm{Xiao}^{2^{*}}$, Yicheng Wang ${ }^{2}$, Hejia Wang ${ }^{2}$ and Ya Huang ${ }^{2}$

${ }^{1}$ Department of Hydraulic Engineering, Tsinghua University, Beijing, China

${ }^{2}$ Department of Water Resources, China Institute of Water Resources and Hydropower Research, Beijing, China

*Corresponding author: Xiao W, Department of Hydraulic Engineering, Tsinghua University, Beijing, China, Tel: +254738974888; E-mail: xwsen998@163.com

Received: October 15, 2018; Accepted: October 22, 2018; Published: October 30, 2018

Copyright: () 2018 Yu Y, et al. This is an open-access article distributed under the terms of the Creative Commons Attribution License, which permits unrestricted use, distribution, and reproduction in any medium, provided the original author and source are credited.

\begin{abstract}
Nearly $60 \%$ of river slopes in developed countries are treated with ecological slope protection technologies. Ecological river revetment has become a main focus in slope protection development projects. At present, the academic research on carbon emission reduction focuses on petroleum exploitation, agricultural production, transportation and residential life, with minor consideration of carbon emissions from river slope protection projects. This study assesses the carbon emissions from structural slope and ecological slope riverbeds, the impact of carbon emissions from ecological slopes on climate in China and analyses the contribution of ecological slope protection to the reduction of carbon dioxide emissions. Results show that ecological slopes can reduce carbon emissions significantly, by $93.12 \%$ compared to structural slopes, with construction costs also reduced by $37 \%$. And river ecological slope protection technologies will provide an important contribution to the reduction of China's carbon emissions.
\end{abstract}

Keywords: River slope; Ecological slope; Carbon emission reduction; Climate; Analyze; China

\section{Introduction}

Over the past century, the global average land surface temperature has risen by $0.6^{\circ} \mathrm{C}( \pm 0.2)$, with the increase in anthropogenic greenhouse gas concentrations considered to be the major cause [1]. Research has shown that human activity is a major cause of rising atmospheric carbon concentrations [2,3], driving global warming [4-6]. Global warming is responsible for various climatic changes and anomalies, have a significant and profound impact on a global scale [7]. Currently, China is the largest energy consumer and $\mathrm{CO}_{2}$ emitter globally [8], however most research in this field has focused on petroleum exploitation, agricultural production, transportation and residential aspects.

Globally, less is known about the carbon emissions associated with engineered slopes. According to statistics, the construction market of China is the largest in the world, with the energy consumption associated with building material production accounting for about $30 \%$ of the total energy consumption in China at present [9] cation of the environmental impact of slope protection projects. According to the China Energy Statistical Yearbook, in 2015 manufacturing accounted for $56.97 \%$ of the total energy consumption in China, among which coal consumption accounted for $45.21 \%$ of the total coal consumption, coke consumption accounted for $99.06 \%$ of the total coke consumption, crude oil consumption accounted for $98.04 \%$ of the total crude oil consumption, and natural gas consumption accounted for $37.2 \%$ of the total natural gas consumption [10]. Manufacturing and extractive industries are China's major source of carbon emissions. The comprehensive energy consumption associated with slope engineering materials includes industrial products such as cement, steel and geotextiles, which consume more energy than natural materials, and are widely used in slope works. The use of ecological slope technologies have aesthetic advantages in urban environments and reduce the use of synthetic building materials, lowering the carbon emissions associated with construction materials. At present, there are to our knowledge no dedicated studies assessing the advantages of ecological slopes in the reduction of carbon emissions.

Based on the carbon emissions factors of building materials commonly used in slope protection projects, this study selects two types of structural and ecological slope to calculate the carbon emissions associated with the construction of river slopes. Furthermore, the carbon storage capacity of green plants used in ecological slopes is considered. By combining these results with analysis of the climate scenario in China, the contribution of ecological slopes in China are evaluated, for the reduction of carbon emissions and improvement of the climate and environment.

\section{Materials and Methods}

\section{Study area}

Panjing is a city-river in Shanghai, its main channel is level VI (Figure 1). The average width of the main section of the Panjing River mouth is about $48 \mathrm{~m}$, with an average annual depth of $2.60 \mathrm{~m}$, although the designed water level is $4.00 \mathrm{~m}$, the highest navigable water level is $3.50 \mathrm{~m}$ and the lowest navigable water level is $2.30 \mathrm{~m}$. The upper elevation reaches $4.50 \mathrm{~m}$ reducing to $-1.00 \mathrm{~m}$ at its lowest elevation. The area studied belongs to the Panjing River revetment, located at Luodian Town and the east bank of the Panjing River, in Baoshan District, covering a total length of $871 \mathrm{~m}$. Geological exploration has shown that the surface layer of the foundation soil in this area is composed of anthropogenic landfill, while the Q4 quaternary holocene sediments are composed of gray silty clay.

The Panjing River revetment project used an ecological bag slope construction technique. In order to compare the impact of ecological 
Page 2 of 6

systems on the carbon emissions associated with slope protection projects, the carbon emissions of structural slope construction were also assessed in a region near the Panjing revetment.

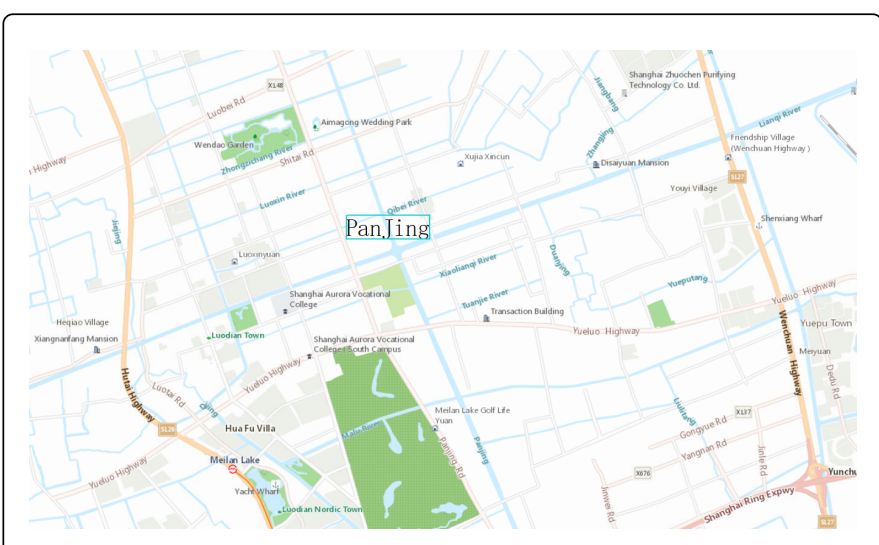

Figure 1: Panjing revetment location.

\section{Methodology}

\section{Emission coefficient method}

The emission coefficient method was applied to estimate the construction process energy consumption [11]. Under normal technical economy and management conditions, this method measures the total carbon emissions based on the statistical average per unit of production. Knowledge of the units of energy consumed under different construction conditions is required, providing the advantage of relevant and accurate data.

\section{Inventory analysis}

Inventory analysis is a process of simplifying and quantifying the performance of complex environmental substances, to establish the input and output of materials in functional units [12]. This system assesses material input and environmental output throughout the entire life cycle of a construction, product, service, or activity [13].

Process-based inventory analysis assesses the full system, divided into different unit activities in the production or construction process. Through input and output analysis of unit activities or processes, accurate input and output data lists are formed corresponding to the unit activity or process. The exchange between the system interior with the external environment is assessed. Process-based inventory analysis can provide a more comprehensive and accurate calculation of the carbon emissions of building material production and use.

\section{Greenhouse gas emissions scenario}

Greenhouse gas emissions scenarios were applied as the basis for climate change projections. Representative concentration pathways (RCPs) were applied to represent four greenhouse gas concentration scenarios, as established by the Intergovernmental Panel on Climate Change (IPCC) Fifth Assessment Report, to represent a range of greenhouse gas concentrations levels (RCP 2.6 (low), RCP 4.5 (medium low), RCP 6.0 (high) and RCP8.5 (high)). This study uses the emission coefficient method and process-based inventory analysis to calculate carbon emissions during the construction of a slope protection system. The greenhouse gas emission scenario was used to analyze the impact of slope protection projects on the climate and environment in the region.

\section{Slope engineering data}

The main structure of the structural slope comprised a side ditch, with slope protection, anchor engineering, slope reinforcement and retaining structures. The side ditch was made of M7.5 mortar rubble; slope protection was made of $\mathrm{C} 15$ concrete; the skeleton slope was made of M7.5 mortar and C15 concrete; expansion joints were made of asphalt hemp; the filter layer was made of sand-gravel and the drainage holes were made of PVC pipe; the anchor layer was made of M30 cement mortar and anchor steel reinforcements; C15 concrete, dry masonry, pebbles and medium gravel were used for slope reinforcement; the retaining wall was made of C25 stone concrete; the filter layer was made of sandy gravel; the anti-seepage layer was made of $\mathrm{C} 25$ concrete and the check ladder was built from reinforcement steel; railings were made of C25 concrete; and PVC pipe was used for drain holes. The materials and quantities used in the engineering of the structural slope are shown in Table 1.

\begin{tabular}{|c|c|c|c|c|}
\hline $\begin{array}{l}\text { Serial } \\
\text { number }\end{array}$ & \multicolumn{2}{|l|}{ Category } & Unit & Value \\
\hline 1 & \multicolumn{2}{|c|}{ Side ditch (M7.5 mortar) } & $\mathrm{m}^{3}$ & 362.3 \\
\hline 2 & \multirow{5}{*}{$\begin{array}{l}\text { Protective } \\
\text { engineering }\end{array}$} & C15 concrete & $\mathrm{m}^{3}$ & 48 \\
\hline 3 & & Skeleton protective & $\mathrm{m}^{3}$ & 508 \\
\hline 4 & & Masonry mound slope & $\mathrm{m}^{3}$ & 4487 \\
\hline 5 & & $\begin{array}{l}\text { Filter layer (sandy } \\
\text { gravel) }\end{array}$ & $\mathrm{m}^{3}$ & 175 \\
\hline 6 & & Drainage holes (PVC) & $\mathrm{m}$ & 862 \\
\hline 7 & \multirow{2}{*}{ Anchor engineering } & Rebar & $\mathrm{kg}$ & 42239 \\
\hline 8 & & M30 cement mortar & $\mathrm{m}^{3}$ & 13 \\
\hline 9 & \multicolumn{2}{|l|}{ Reinforcement project } & $\mathrm{m}^{3}$ & m3 \\
\hline 10 & \multirow{3}{*}{ Retaining wall } & Wall (C25 concrete) & $\mathrm{m}^{3}$ & 4337 \\
\hline 11 & & Check ladder (rebar) & $\mathrm{kg}$ & 170 \\
\hline 12 & & drain hole (PVC) & $\mathrm{m}$ & 748 \\
\hline
\end{tabular}

Table 1: The quantity of materials used to engineer the structural slope.

\begin{tabular}{|l|l|l|l|}
\hline Serial number & Category & Unit & Value \\
\hline 1 & Cement & $\mathrm{t}$ & 194.70 \\
\hline 2 & Medium sand & $\mathrm{t}$ & 664.28 \\
\hline 3 & C15 concrete & $\mathrm{m}^{3}$ & 294 \\
\hline 4 & C25 concrete & $\mathrm{m}^{3}$ & 3542 \\
\hline 5 & Rebar & $\mathrm{t}$ & 4.24 \\
\hline 6 & Sandy gravel & $\mathrm{m}^{3}$ & 213 \\
\hline 7 & Dry masonry & $\mathrm{m}^{3}$ & 95 \\
\hline 8 & Medium gravel & $\mathrm{m}^{3}$ & 38 \\
\hline
\end{tabular}


Page 3 of 6

\begin{tabular}{|l|l|l|l|}
\hline 9 & PVC pipe & $\mathrm{m}^{2}$ & 1610 \\
\hline 10 & Fuel consumption & $\mathrm{t}$ & 1.02 \\
\hline
\end{tabular}

\section{$C=\Sigma \beta i Q i$}

(1)

Where $i=1,2,3, \ldots \ldots \beta$ is the carbon emission coefficient of the raw material; and $Q$ is the level of energy consumption.

Table 2: Inventory of structural slope materials.

The inventory list of the structural slope is shown in Table 2. The length of the structural slope is $1017 \mathrm{~m}$. Both the ecological and structural slopes were of a similar scale. The main components in construction of the ecological slope were earth, concrete, ecological bag revetments, grass (sowed by spraying), imitation wood fences (concrete), and maintenance projects. The materials and quantities used for ecological bag slope construction are shown in Table 3, while the inventory list of materials used in the construction of the ecological bag slope is shown in Table 4 .

\begin{tabular}{|c|c|c|c|c|}
\hline $\begin{array}{l}\text { Serial } \\
\text { number }\end{array}$ & \multicolumn{2}{|c|}{ Category } & Unit & Value \\
\hline 1 & \multicolumn{2}{|c|}{ Earthworks } & $\mathrm{m}^{3}$ & 32662.5 \\
\hline 2 & \multicolumn{2}{|c|}{ Precast square piles } & $\mathrm{m}^{3}$ & 326.625 \\
\hline 3 & \multicolumn{2}{|c|}{ Concrete block } & $\mathrm{m}^{3}$ & 8.71 \\
\hline 4 & \multicolumn{2}{|c|}{ Ecological bag retaining wall } & Piece & 6148 \\
\hline 5 & \multicolumn{2}{|c|}{ Ecological bag revetment } & Piece & 9460 \\
\hline 6 & \multicolumn{2}{|c|}{ Spraying grass planting } & $\mathrm{m}^{2}$ & 4690.5 \\
\hline 7 & \multirow{3}{*}{$\begin{array}{l}\text { Fence } \\
\text { project }\end{array}$} & $\begin{array}{l}\mathrm{C} 25 \text { reinforced } \\
\text { concrete base }\end{array}$ & $\mathrm{m}^{3}$ & 174.2 \\
\hline 8 & & $\begin{array}{l}\text { C10 plain } \\
\text { concrete bedding }\end{array}$ & $\mathrm{m}^{3}$ & 4.355 \\
\hline 9 & & $\begin{array}{l}\text { Imitation wood } \\
\text { fence }\end{array}$ & $10 \mathrm{~m}$ & 87.1 \\
\hline 10 & \multicolumn{2}{|c|}{ Conservation projects } & $\mathrm{m}^{2}$ & 4690.5 \\
\hline
\end{tabular}

Table 3: The quantity of materials used to engineer the ecological bag slope.

\begin{tabular}{|l|l|l|l|}
\hline Serial number & Category & Unit & Value \\
\hline 1 & Cement & $\mathrm{t}$ & 230 \\
\hline 2 & Coarse sand & $\mathrm{m}^{3}$ & 268 \\
\hline 3 & Fine sand & $\mathrm{m}^{3}$ & 126 \\
\hline 4 & Rebar & $\mathrm{t}$ & 1.6 \\
\hline 5 & Ecological bag & $\mathrm{m}^{2}$ & 15608 \\
\hline 6 & Plant seeds & $\mathrm{kg}$ & 26 \\
\hline 7 & Imitation wood fence & $10 \mathrm{~m}$ & 87.1 \\
\hline 8 & Fuel consumption & $\mathrm{t}$ & 1216.7 \\
\hline
\end{tabular}

Table 4: Inventory of ecological bag slope materials.

\section{Calculation of carbon emission in slope protection}

Carbon emissions were calculated using the formula shown in Equation (1):

\section{Carbon emission factors}

The main raw materials required for slope protection projects are block stones and gravel materials, with crushed stone used for cushioning and broken stone used for concrete production, both processed from block stone. There are four stages to processing: stone mining, processing, construction site production and transportation. The comprehensive energy consumption of raw materials and their production process were assessed using the formula shown in Equation (2):

\section{$\mathrm{W}=\mathrm{W} 1+\mathrm{W} 2+\mathrm{W} 3+\mathrm{W} 4$}

Where W1 represents energy consumption in the material extraction process; W2 represents the energy consumption of material processing; W3 represents the energy consumption of on-site finished product manufacturing; and W4 represents transportation energy consumption, an important aspect that affects the environmental impact of slope engineering materials, with gasoline use applied the international common carbon emission coefficient of $2.361 \mathrm{kgC} / \mathrm{L}$ [14]. The carbon emission coefficients for energy consumption of raw materials used in slope construction are shown in Table 5.

\begin{tabular}{|l|l|l|}
\hline Serial number & Category & $\begin{array}{l}\text { Carbon } \\
\text { coefficient }\end{array}$ \\
\hline 1 & Cement & $80.6 \mathrm{kgC} / \mathrm{t}$ \\
\hline 2 & Sandy gravel & $3.08 \mathrm{kgC} / \mathrm{m}^{3}$ \\
\hline 3 & Macadam & $2.39 \mathrm{kgC} / \mathrm{m}^{3}$ \\
\hline 4 & Dry masonry & $0.49 \mathrm{kgC} / \mathrm{m}^{3}$ \\
\hline 5 & Cobble-stone & $2.39 \mathrm{kgC} / \mathrm{m}^{3}$ \\
\hline 6 & Concrete & $38.55 \mathrm{kgC} / \mathrm{m}^{3}$ \\
\hline 7 & Rebar & $159.02 \mathrm{~kg} / \mathrm{m}^{3}$ \\
\hline 8 & PVC & $110.89 \mathrm{kgC} / \mathrm{m}^{2}$ \\
\hline 9 & Ecological bag & $0.16 \mathrm{kgC} / \mathrm{m}^{2}$ \\
\hline 10 & Gasoline & $2.361 \mathrm{kgC} / \mathrm{L}$ \\
\hline
\end{tabular}

Table 5: Carbon emission coefficients for energy consumption of the main building materials used in slope construction.

The carbon emission factor for transportation of major energy is taken from the IPCC (Intergovernmental Panel on Climate Change).

\section{Carbon emissions from structural slope construction}

Cement is mainly transported over-land, covering an average distance of $100 \mathrm{~km}$ in this region (assuming that most cement comes from the local cement plant), resulting in a fuel consumption per ton of cement of $5.29 \mathrm{~kg}$. Therefore, the total fuel consumption required for the transportation of engineering material is $746.72 \mathrm{~L}$. Bad on the amount of construction materials and carbon emission coefficients, the calculated carbon emissions for the structural slope are shown in Table 6. 
Page 4 of 6

\begin{tabular}{|c|c|c|c|c|c|c|c|}
\hline \multirow{2}{*}{ Serial number } & \multirow{2}{*}{ Category } & \multicolumn{2}{|c|}{ Quantities } & \multicolumn{2}{|c|}{ Carbon emission factor } & \multirow{2}{*}{$\begin{array}{l}\text { Carbon } \\
\text { emission } \\
\mathbf{t}\end{array}$} & \multirow[t]{2}{*}{$\begin{array}{l}\text { Carbon } \\
\text { emission ratio }\end{array}$} \\
\hline & & Unit & Value & Unit & Value & & \\
\hline 1 & Cement & $\mathrm{t}$ & 194.7 & $\mathrm{kgC} / \mathrm{t}$ & 80.6 & 15.69 & $4.29 \%$ \\
\hline 2 & Sand,gravel & $\mathrm{m}^{3}$ & 6898.84 & $\mathrm{kgC} / \mathrm{m}^{3}$ & 3.08 & 21.25 & $5.79 \%$ \\
\hline 3 & Concrete & $\mathrm{m}^{3}$ & 3836 & $\mathrm{kgC} / \mathrm{m}^{3}$ & 38.55 & 147.88 & $40.40 \%$ \\
\hline 5 & Rebar & $\mathrm{m}^{3}$ & 5.41 & $\mathrm{kgC} / \mathrm{m}^{3}$ & 159.02 & 0.860 & $0.23 \%$ \\
\hline 7 & Dry masonry & $\mathrm{m}^{3}$ & 95 & $\mathrm{kgC} / \mathrm{m}^{3}$ & 0.49 & 0.0466 & $0.013 \%$ \\
\hline 8 & Cobble-stone & $\mathrm{m}^{3}$ & 38 & $\mathrm{kgC} / \mathrm{m}^{3}$ & 2.39 & 0.0908 & $0.025 \%$ \\
\hline 9 & PVC pipe & 2 & 1610 & $\mathrm{kgC} /{ }^{2}$ & 110.89 & 178.53 & $48.76 \%$ \\
\hline 10 & Fuel consumption & L & 746.72 & $\mathrm{kgC} / \mathrm{L}$ & 2.361 & 1.76 & $0.49 \%$ \\
\hline \multicolumn{2}{|c|}{ Total carbon emission } & \multicolumn{6}{|c|}{$366.11 \mathrm{t}$} \\
\hline
\end{tabular}

Table 6: Carbon emissions generated by the construction of the structural slope.

\section{Carbon emissions from ecological slope construction}

The imitation wood fences used are commonly made of concrete, resulting in carbon emission coefficient for wooden fences being equal to the carbon emission coefficients for concrete. The calculation method for cement transportation fuel consumption is the same as that of structural slope, assuming an average distance of $100 \mathrm{~km}$, with fuel consumption per ton of cement being $5.29 \mathrm{~kg}$. Therefore, the total fuel consumption for the transportation of materials is $882.11 \mathrm{~L}$. Based on the amount of construction materials used and carbon emission coefficients, the calculated carbon emissions for the construction of the ecological bag slope are shown in Table 7.

\begin{tabular}{|c|c|c|c|c|c|c|c|}
\hline \multirow{2}{*}{$\begin{array}{l}\text { Serial } \\
\text { numbe } \\
r\end{array}$} & \multirow[t]{2}{*}{ Category } & \multicolumn{2}{|c|}{ Quantities } & \multicolumn{2}{|c|}{$\begin{array}{l}\text { Carbon } \\
\text { emission } \\
\text { factor }\end{array}$} & \multirow{2}{*}{$\begin{array}{l}\text { Carbon } \\
\text { emissio } \\
\text { n }\end{array}$} & \multirow[t]{2}{*}{$\begin{array}{l}\text { Carbon } \\
\text { emissio } \\
\text { n ratio }\end{array}$} \\
\hline & & Unit & Value & Unit & Value & & \\
\hline 1 & Cement & $t$ & 230 & $\mathrm{kgC} / \mathrm{t}$ & 80.6 & 18.54 & $73.41 \%$ \\
\hline 2 & $\begin{array}{l}\text { Sand, } \\
\text { gravel }\end{array}$ & $\mathrm{m}^{3}$ & 394 & $\mathrm{kgC} / \mathrm{m}^{3}$ & 3.08 & 1.21 & $4.76 \%$ \\
\hline 3 & Rebar & $\mathrm{m}^{3}$ & 2.04 & $\mathrm{kgC} / \mathrm{m}^{3}$ & $\begin{array}{l}159.0 \\
2\end{array}$ & 0.32 & $1.19 \%$ \\
\hline 4 & $\begin{array}{l}\text { Ecological } \\
\text { bag }\end{array}$ & $\mathrm{m}^{2}$ & 15608 & $\mathrm{kgC} / \mathrm{m}^{2}$ & 0.16 & 2.5 & $9.92 \%$ \\
\hline 5 & $\begin{array}{l}\text { Imitation } \\
\text { wood fence }\end{array}$ & $\mathrm{m}^{3}$ & 16 & $\mathrm{kgC} / \mathrm{m}^{3}$ & 38.55 & 0.62 & $2.38 \%$ \\
\hline 6 & $\begin{array}{l}\text { Fuel } \\
\text { consumptio } \\
\mathrm{n}\end{array}$ & $\mathrm{L}$ & 882.11 & $\mathrm{kgC} / \mathrm{L}$ & 2.361 & 2.08 & $8.33 \%$ \\
\hline \multicolumn{2}{|c|}{ Total carbon emission } & \multicolumn{6}{|c|}{$25.27 \mathrm{t}$} \\
\hline
\end{tabular}

Table 7: Carbon emissions generated by the construction of the ecological bag slope.

\section{Results}

According to the results of calculations, the carbon emissions from structural slope construction were $366.11 \mathrm{t}$, with concrete and PVC piping contributing the highest proportion of carbon emissions at $147.88 \mathrm{t}$ and $178.53 \mathrm{t}$, respectively, accounting for $40.4 \%$ and $48.76 \%$ of the total. The carbon emissions generated during ecological bag slope construction were $25.27 \mathrm{t}$, with cement accounting for the highest proportion of carbon emissions at $18.54 \mathrm{t}$, accounting for $73.41 \%$ of the total. The carbon emissions generated by cement use in the structural slope and ecological bag slope were similar, at $15.69 \mathrm{t}$ and $18.54 \mathrm{t}$, respectively. The use of PVC piping in the structural slope resulting in carbon emissions of $178.53 \mathrm{t}$, accounting for $48.76 \%$ of the total, whilst this material was not used for construction in the eco-bag slope. The carbon emissions produced by ecological slope construction were 13fold lower than the emissions generated by structural slope construction, although concrete and cement were still the main components in slope construction.

The ecological bag slope protection project cost a total of 1.0812 million yuan, resulting in a significant $37 \%$ reduction in construction costs as compared to the structural slope protection project, which cost a total of 171.64 million yuan.

In the construction of the ecological bag slope, the original trees present along the slope were retained and plants that exhibit strong vitality and rapid growth were planted. After two few weeks of construction, the vegetative growth covered the surface of the slope, with 32 grams of carbon dioxide absorbed per day, per square meter of grass. The grass covered area of the ecological bag slope was $4690.5 \mathrm{~m}^{2}$, resulting in the potential absorption of $150 \mathrm{~kg}$ of carbon dioxide per day. Therefore, $25.27 \mathrm{t}$ of carbon emissions generated by ecological bag slope construction could be absorbed and purified by the surrounding plants in about 168 days.

According to the Yearbook of China's Water Conservancy, there is a total of $277293 \mathrm{~km}$ of river embankment in China. Based on the findings of this study, the calculation range of carbon emissions for slope protection works can be expanded. If all the slope constructions 
adopt traditional construction technologies, the associated carbon emissions for structural slopes would be in the region of $101.52 \times 10^{6} \mathrm{t}$. Comparatively, if using ecological slope protection systems, the associated carbon emissions were in the range of $8.9 \times 10^{6} \mathrm{t}$. These results show that the use of ecological systems can reduce the carbon emissions from slope protection by about $92 \%$, which would contribute significantly to the improvement of both the climate and environment in China.

\section{China's climate scenario}

According to China Climate Change Monitoring Bulletin 2013, the mean surface temperature of waterbodies in China showed a significant upward trend from 1901 to 2013, with distinct decadal variations. Over the past 100 years (1914 2013), the average surface temperature of waterbodies in China increased by $0.91^{\circ} \mathrm{C}$, while 2013 was the fourth warmest year on record in the region since 1901, with an average surface temperature of $9.4^{\circ} \mathrm{C}, 1.0^{\circ} \mathrm{C}$ above average. In 2013 , the total population of mainland China was 1.361 billion, with future population predictions for China suggesting steady growth and a population peak around 2030. China's future economic growth rate is predicted to remain at a high level compared with the past 30 years. By 2030, it has been predicted that China will have completed the process of industrialization and urbanization, resulting in a reduction in growth of energy demand following this and possibly a reduction in $\mathrm{CO}_{2}$ emissions.

According to the Third National Assessment Report on Climate Change, under the scenario of representative concentration pathways (RCPs), the average regional temperature in China will continue to rise. The warming extent and this trend remains small prior to 2030, although after 2030 different RCPs show different characteristic outcomes.

The regional climate change prediction established for China using the regional climate model RegCM4.0, shows an increasing trend in the average regional climate change in China and a significantly higher temperature increase in the RCP8.5 scenario than that of RCP4.5. After the middle of the 21st century, the warming induced by the RCP4.5 scenario stabilized, while RCP8.5 continued to increase. In the late 21 st century, under the RCP 4.5 and 8.5 scenarios, the annual average temperature rises in China were $1.8^{\circ} \mathrm{C}$ and $3.8^{\circ} \mathrm{C}$, respectively.

\section{Conclusion}

When comparing the total carbon emissions generated by the construction of both kinds of slope, the structural slope was significantly larger than the ecological bag slope. A greater quantity of materials were used for structural slope construction, such as sand stone, concrete, PVC and steel rebar, contributing to the greater carbon emissions associated with structural slope protection constructions. The use of ecological slope protection technology has reduced carbon emissions by $93.12 \%$. In the present study, the characteristics of plants were shown to contribute to the effectiveness of ecological slopes, reducing the amount of construction materials required and the environmental impact of slope construction. As ecological slope plants are planted during construction, they can absorb carbon dioxide and purify the exhaust gas generated throughout construction, which greatly reduces the impact of construction on the environment as well as providing further environmental benefits following this.

In terms of construction costs, the cost of river slope construction using ecological systems were significantly lower than that of the structural slope, with a $37 \%$ reduction in cost. These findings show that the application of ecological slope protection technologies greatly reduce construction costs and improve environmental conditions, as well as providing the benefit of economic development.

According to Figure 2, China's embankment projects were mainly concentrated in economically developed areas in the central and southeastern regions. Using ecological technologies to carry out slope protection projects can potentially control the negative impact of urban construction on the surrounding atmospheric environment, while supporting economic development. According to the analysis of economic costs and $\mathrm{CO}_{2}$ emission trends, if the future climate develops according to the RCP4.5 scenario and China adopt ecological technologies to rehabilitate river slopes, as well as formulating and strictly implementing policies related to ecological restoration, it could limit the emission of greenhouse gases such as $\mathrm{CO}_{2}$, supporting the target of controlling the annual average temperature of $1.8^{\circ} \mathrm{C}$, effectively reduce construction costs and promote economic development.

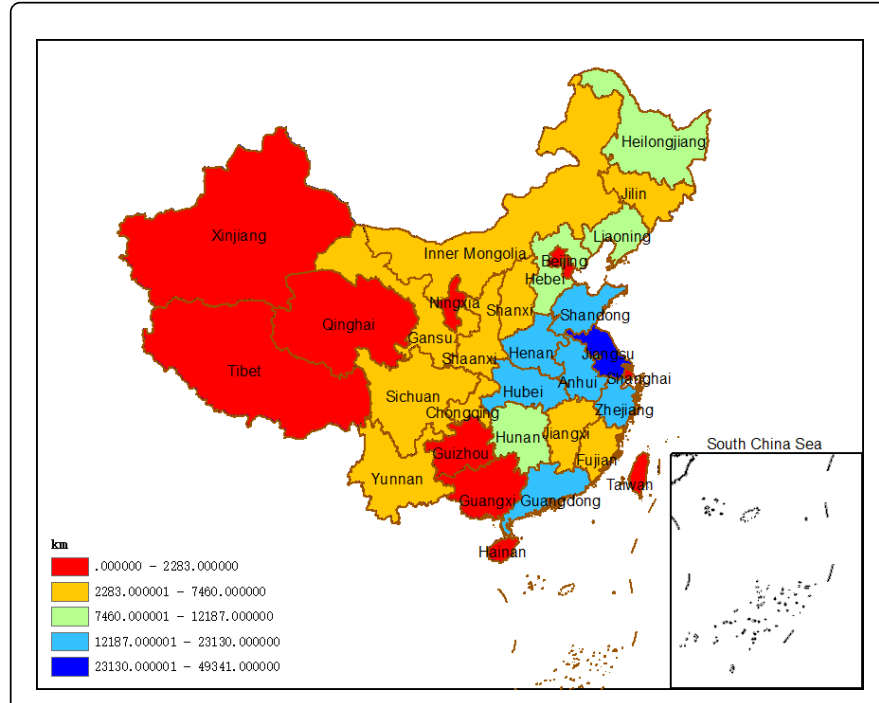

Figure 2: Schematic diagram of the river embankment distribution in China's provinces.

The carbon emissions generated by the process of water conservancy construction, are mainly associated with the production and transportation of construction materials. This paper studies the construction associated carbon emissions from both structural and ecological slopes, from the perspective of construction materials and transportation, quantifying the potential reduction in carbon emissions that could be provided by implementing ecological slope designs. This research shows that the effect of ecological slope construction in the reduction of carbon emissions is significantly beneficial. Combining artificial and natural engineering technologies is an effective way to reduce carbon emissions. Furthermore, the procurement of construction materials is a significant contributing factor, with the selection of low-carbon green materials being beneficial to the overall environmental impact.

Due to the complicated construction processes associated with slope protection projects, this study simplified the construction, material production and transportation processes involved in slope protection engineering. When calculating the construction carbon emissions, the 
Citation: Yu Y, Xiao W, Wang Y, Wang H, Huang Y (2018) Assessment of the Carbon Emission Reduction Effects of Ecological River Slope Construction in China. J Environ Anal Toxicol 8: 589. doi:10.4172/2161-0525.1000589

Page 6 of 6

influence of economic, social and other factors on carbon emissions, were not considered. Therefore, future research on carbon emissions associated with slope protection projects can improve the accuracy of calculations, with comprehensive analysis of the impact of various factors on carbon emissions of slope protection constructions.

\section{Acknowledgements}

The research was jointly funded by the National Key Research and Development Program (during the 13th Five-Year Plan) (no. 2017YFC0404701). First and foremost, I would like to show my deepest gratitude to my supervisor, Dr. Weihua Xiao, a respectable, responsible and resourceful scholar, who has provided me with valuable guidance in every stage of the writing of this thesis. Without his enlightening instruction, impressive kindness and patience, I could not have completed my thesis. His keen and vigorous academic observation enlightens me not only in this thesis but also in my future study. I shall extend my thanks to Dr. Xiao for all his kindness and help. I would also like to thank all my teachers who have helped me to develop the fundamental and essential academic competence. My sincere appreciation also goes to the teachers and students from Tsinghua University and China Institute of Water Resources and Hydropower Research, who participated this study with great cooperation. Last but not least, I' d like to thank all my friends, especially my three lovely roommates, for their encouragement and support.

\section{References}

1. IPCC (2007) IPCC 2007: Summary for Policymakers. Cambridge University Press.

2. Den Elzen M, Admiraal A, Roelfsema M, van Soest H, Hof AF, et al (2016) Contribution of the G20 economies to the global impact of the Paris agreement climate proposals. Climatic Change 137: 655-665.
3. Van Vuuren DP, Van Soest H, Riahi K, Clarke L, Krey V, et al. (2016) Carbon budgets and energy transition pathways. Environmental Research Letters 11: 075002 .

4. Kellstedt PM, Zahran S, Vedlitz A (2008) Personal efficacy, the information environment, and attitudes toward global warming and climate change in the United States. Risk Analysis: An International Journal 28: 113-126.

5. Rosenzweig C, Karoly D, Vicarelli M, Neofotis P, Wu Q (2008) Attributing physical and biological impacts to anthropogenic climate change. Nature 453: 353.

6. Hautier Y, Tilman D, Isbell F, Seabloom EW, Borer ET, et al. (2015) Anthropogenic environmental changes affect ecosystem stability via biodiversity. Science 348: 336-340.

7. Fischer EM, Knutti R (2015) Anthropogenic contribution to global occurrence of heavy-precipitation and high-temperature extremes. Nature Climate Change 5: 560.

8. Wang J, Lv K, Bian Y, Cheng Y (2017) Energy efficiency and marginal carbon dioxide emission abatement cost in urban China. Energy Policy 105: 246-255.

9. Li L, Li L, Zhou J, Dai J (2012) Calculation and evaluation of comprehensive energy consumption and carbon emissions of revetment works materials. Yangtze River 43: 15.

10. China Energy Statistics Division (2016) China Energy Statistics Yearbook.

11. Haiqing H, Shujing $\mathrm{W}$, Long $\mathrm{S}$ (2013) Interaction among climate change, fire disturbance and ecosystem carbon cycle. Arid Land Geography 36: 57-75.

12. Udo de Haes HA (1996) Towards a methodology for life cycle impact assessment. Society of Environmental Toxicology and Chemistry.

13. Fay R, Treloar G, Iyer-Raniga U (2000) Life-cycle energy analysis of buildings: a case study. Building Research \& Information 28: 31-41.

14. IPCC (2007) Climate Change 2007: The Physical Science Basis. Cambridge University Press. 